Іігнатов О. М., к.ю.н., с.н.с., завідувач кафедри трудового права, права соціального забезпечення та кримінального права Інституту економіки та права (філія) ОУП ВПО «Академія праці та соціальних відносин» в м. Севастополі

\title{
ЛАТЕНТНІСТЬ ВБИВСТВ ЯК СУМІЖНИЙ СТАН
}

Анотація. Стаття присвячена дослідженню факторів латентності насильницької злочинності на прикладі такого злочину як вбивство. Встановленні фактори латентності вбивств як суміжного стану та надана їх загальна характеристика.

Ключові слова: латентність, вбивство, фактор, суміжний стан.

Постановка проблеми. Рівень вбивств в країні $€$ тим показником, який в цілому характеризує рівень насильства у суспільстві, а у кінцевому підсумку й рівень злочинності в цілому. Положення справ відносно вбивств $€$ так би мовити узагальнюючою, інтегративною характеристикою криміногенної обстановки в цілому та більш того - індикатором всієї соціально-правової ситуації в країні $[2,14]$. В свою чергу, як слушно зазначив А. Ф. Зелінський, порівняно низький коефіцієнт злочинності в Україні - це результат насамперед винятково високої латентності (прихованості) злочинів і погано поставленого обліку [4, 111]. Залежно від механізму утворення латентної злочинності слід виділяти такі іiі видові класи (групи): 1) природна латентність - сукупність фактично вчинених злочинів, про які ні правоохоронним органам, ні посадовим особам, ні громадянам нічого невідомо; 2) штучна латентність - злочини, відомі окремим громадянам і посадовим особам, але ні ті, ні інші з різних мотивів не повідомляють про них у відповідні органи; 3) латентність як суміжний стан -злочинні діяння, факт вчинення яких став відомий потерпілим чи стороннім особам, але той, хто виявив їх, через неясність ситуації чи неправильну правову оцінку не повідомляє про це в органи кримінальної юстиції; 4) приховування злочинів від обліку - злочини, про які органу, що веде боротьбу зі злочинністю, стало відомо, але його представник з різних причин не реєструє виявлений злочин [14, 71-72]. Саме вказана класифікація видів латентних злочинів (особливо з урахуванням виокремлення приховування злочинів від обліку), на наш погляд, дозволяє більш повно дослідити фактори існування як латентної злочинності в цілому, так й окремих видів злочинів, зокрема вбивств. При цьому одним з найбільш складних питань латентності вбивств $€$ латентність вбивств як суміжний стан.

Аналіз останніх досліджень та виокремлення нерозв'язаних проблем. Дослідженню латентної злочинності як однієї з найбільш актуальних проблем кримінологічної наук присвячені роботи Р. М. Акутаєва, К. К. Горяїнова, І̇. М. Даньшина, Г. І̇. Забрянського, А. Ф. Зелінського, О. Г. Кальмана, О. О. Ковалкіна, А. О. Конєва, О. М. Ларіна, Д. А. Лі, В. В. Лунєєва, Г. А. Матусовського, В. Ф. Оболенцева, В. В. Панкратова, В. М. Поповича, О. Г. Фролової, О. С. Шляпочнікова, Т. К. Щеглової та ін. Однак, незважаючи на значну увагу, що приділяється даній проблематиці, залишається чимало питань щодо рівня латентності злочинності як в цілому, так й окремих видів злочинів, факторів, що іiі обумовлюють та самого механізму латентизації. Ці питання обумовлені як складністю досліджуваної проблематики, так й динамічністю розвитку соціуму та злочинності як його складової. Зазначене в повній мірі стосується й насильницької злочинності, перш за все, такого злочину як вбивство.

Метою даної статті є дослідження латентності вбивств як суміжного стану. Ї̈̈ новизна полягає у встановленні та наданні загальної характеристики факторів латентності вбивств як суміжного (між природною та штучною латентністю) стану.

Виклад основного матеріалу. Перш за все, латентність вбивств як суміжний (між природною та штучною латентністю) стан обумовлюється існуванням факторів, через які особи, які виявили факт їх вчинення, через неясність ситуації чи неправильну правову 
оцінку не повідомляють про це в правоохоронні органи (або належним чином чи взагалі не реєструють їх). Враховуючи специфіку вбивства, мова повинна йтися про професійну діяльність працівників органів охорони здоров'я та правоохоронних органів.

Об’єктивні умови (неможливість встановити причини смерті через складність травм або великий проміжок часу з моменту настання смерті тощо) або недостатність матеріально-технічного забезпечення та/або професійної підготовки працівників органів охорони здоров'я (перш за все, судово-медичних установ) або ж ї професійна несумлінність, сприяють латентизації частини вбивств, які реєструються як випадки «некримінальної» смерті (через самогубство, нещасний випадок, хворобу, неможливість встановити причину смерті тощо).

Що стосується діяльності правоохоронних органів, як зазначають фахівці, злочини проти життя, в тому числі й вбивства, відносяться до числа діянь, при кримінально-правовій оцінці яких зустрічаються значні труднощі, що $€$ наслідком різноманітності різних обставин скоєння цих злочинів, а також ускладненістю, оціночністю и небезспірністю деяких кримінально-правових і кримінологічних ознак, які доводиться враховувати в процесі кваліфікаціï. Однак різного роду погрішності при кваліфікації вбивств, що допускаються слідчими органами і судами, пояснюються і низкою факторів, не пов'язаних з погрішностями законодавства: складностями в розмежуванні суміжних складів злочинів, неповним встановленням та/або неглибоким дослідженням обставин вчинення вбивства в процесі розслідування справи. Слідчо-судова діяльність по оцінці вбивства іноді поверхнева і формальна; в ході іiі частіше досліджуються лише об'єктивні (зовнішні) ознаки та не приділяється відповідного значення питанням вивчення в кожному окремому випадку суб'єктивних факторів (в тому числі соціально-психологічних, психологічних, психофізіологічних факторів вчинення вбивства), специфіки і змісту злочинної мотивації [10, 203-204].

Безумовно, беручи до уваги значущість показників рівня вбивств в країні, враховуючи на потужний превентивний потенціал та вплив, у кінцевому підсумку, на формування стратегії кримінологічної політики, адекватна кримінально-правова оцінка злочинного діяння та ефективне його розслідування набуває найважливіше значення. У зв' язку з цим, розглянемо відповідні дві групи факторів, що обумовлюють існування латентності вбивств як суміжного (між природною та штучною латентністю) стану: труднощі кримінальноправової оцінки, пов'язані з недосконалістю кримінального законодавства та недоліками та/або помилками його застосування окремими правозастосувачами.

Як свідчить аналіз відповідних норм кримінального законодавства та практики його застосування, превентивний потенціал кримінально-правових засобів реалізується не в повній мірі. Не останню роль в цьому грає недосконалість кримінального законодавства [7].

Так, тривалий час серед науковців викликає дискусії навіть назва розділу Особливої частини Кримінального кодексу України (надалі $\mathrm{KK})$, у якому містяться норми, що передбачають відповідальність за вбивство та інші злочини проти життя та здоров'я, а також щодо його місця у структурі кримінального закону. На наш погляд, вірною $є$ позиція вчених, які наголошують, що Розділ II Особливої частини повинен мати назву «Злочини проти життя та здоров'я людини», оскільки поняття «людина» й «особа»не рівнозначні. Поняття «людина», охоплюючи їі характеристику як біологічної, живої істоти в цілому, а не лише iï соціальних властивостей (отримання при народженні прав і свобод, здатність самостійно ними володіти, користуватися, розпоряджатися, а також самостійно виконувати встановлені державою обов'язки) $є$ ширшим за обсягом.

Стосовно місця зазначеного розділу у структурі Особливої частини кримінального закону, існуюче положення речей, незважаючи на заперечення фахівців, $є$ виправданим, оскільки, як слушно зазначає В. В. Сташис, національна безпека держави, іiі цілісність та недоторканість $є$ необхідною умовою, базою для всебічної охорони життя та здоров'я особи $[16,6]$.

Вбивство - найбільш тяжкий та небезпечний насильницький злочин. Формулювання ж відповідного складу злочину у кримінальному законі не лише впливає на зміст його юридичних ознак, відповідно, на адекватність та доцільність передбаченого покарання, але й на відображення рівня вчинення даного злочину 
у статистичних даних та, відповідно, спрямованість та ефективність превентивних заходів.

У контексті недосконалості кримінально-правових норм, що передбачають відповідальність за вбивство та їх вдосконалення заслуговують на увагу пропозиції фахівців щодо доцільності виключення з тексту закону вказівки на «протиправність», як ознаку вбивства (оскільки протиправність у теорії кримінального права у цілому розуміється як заборона законом певного діяння, а національне законодавство базується на визначенні поняття злочину, закріпленого в ч. 1 ст. $11 \mathrm{KK}$, в якій встановлено єдине поняття протиправності щодо злочинів, передбачених Особливою частиною КК). Також доцільними, вбачаються пропозиції щодо необхідності виключення (через дане у диспозиції ч. 1 ст. $115 \mathrm{KK}$ поняття вбивства як умисного протиправного заподіяння смерті іншій людині) 3 назв норм, що передбачають відповідальність за вбивство терміну «умисне».

Будь-яке злочинне діяння, у тому числі й вбивство, повинно бути винним. Кримінальний закон передбачає можливість вчинення вбивства як умисно, так й через необережність. На наш погляд, вірною є позиція, відповідно якої вбивство може бути вчинене лише з умисною формою вини, оскільки, як слушно зазначає М. Іे. Хавронюк, заподіяння смерті у разі вчинення умисного діяння та у випадку необережності $€$ два різних за правовим змістом кримінально-правових явища $[18,652]$. Аналіз суб'єктивних ознак (перш за все, інтелектуального та вольового моментів суб'єктивної сторони, а також особливостей мотивації) відповідних складів злочинів, а також відповідних санкцій свідчить, що сам законодавець не ототожнює умисне та необережне заподіяння смерті іншій людині за їх суспільною небезпечністю.

Засудження за необережне заподіяння смерті іншій людині з формулюванням «вбивство» лише сприяє штучному завищенню негативної оцінки з боку суспільства даного діяння та «стигматизації» осіб, які його вчинили, а наявність у статистичній звітності показників щодо необережного заподіяння смерті іншій людині у сукупності вбивств, штучно завищує показники рівня вбивств у країні та сприяє хибній сконцентрованості та скеруванню відповідних превентивних заходів. 3 урахуванням викладеного, назву ст. 119 КК доцільно викласти як: «Заподіяння смерті через необережність».

Абсолютно зайвою в контексті адекватної кваліфікації вчиненого діяння (отже справедливого та ефективного покарання) та статистичного обліку насильницьких посягань $€$, на наш погляд, існуюча сьогодні ч. 2 ст. $121 \mathrm{KK}$ України у частині встановлення відповідальності за умисне тяжке тілесне ушкодження, що спричинило смерть потерпілого. Адже, як свідчить практика, дане злочинне діяння $€$ не чимось іншим як умисним вбивством, специфіка якого полягає лише у тому, що злочинні наслідки віддалені від діяння у часі.

І̇снування даної норми, введеної ще за радянських часів, ефективно знижує гостроту проблеми зростаючого рівня вбивств в нашій (до речі і в інших пострадянських) країні. Практично кожне третє фактичне вбивство потрапляє таким чином у статистичних звітах до групи злочинів проти здоров'я особи. Крім того, на практиці порушені кримінальні справи про нерозкриті вбивства навіть при підтвердженні цих фактів висновками судовомедичних експертиз та інших обставин через деякий час нерідко перекваліфіковуються на вчинення тяжких тілесних ушкоджень зі смертельними наслідками.

Загальною для всіх норм, що передбачають кримінальну відповідальність за вчинення насильницьких злочинів, в тому числі й вбивств, $€$ проблема вдосконалення термінологічної складової. Законодавець при конструюванні насильницьких складів як прямо застосовує термін «насильство», «фізичне насильство», «психічне насильство», «насильницькі дії», так Й інші загальні терміни («завдання удару», «погроза», «примус», «напад», «тероризування» та ін.), в тому числі ті, що характеризують наслідки злочинного діяння («заподіяння смерті», «фізичне страждання», «приниження гідності» та ін.). Однак, використовуючи термін насильство, законодавець не дає його тлумачення, а інші зазначені терміни доволі часто використовує досить непослідовно, допускаючи різне їх тлумачення, або розкриваючи зміст одного терміну через інші, не розкриваючи при цьому зміст останніх. Типовий приклад такої законодавчої «техніки»ст. 126 КК України, у якій «побої», відповідно до ч. 1, визначені законодавцем як «умисне 
завдання удару, побоїв (виокремлено мною O.і.) або вчинення інших насильницьких дій, які завдали фізичного болю і не спричинили тілесних ушкоджень», а «мордування» відповідно до ч. 2 визначене як «ті самі дії, що мають характер мордування (виокремлено мною - О.і. $) \gg[6]$.

Стосовно безпосередньо вбивств, невизначеність, наприклад, у законі поняття хуліганського мотиву (доцільність наявності самої вказівки, на яку у кримінальному законі взагалі викликає сумнів, оскільки, ми цілком погоджуємося з Ю. М. Антоняном, який засуджує традицію пояснювати всі незрозумілі дії хуліганськими мотивами, яка склалася на практиці й у деяких теоретичних роботах, оскільки це $€$ звичайним спрощенням, а нерідко й перекручуванням справжньої природи злочинного діяння $[1,111-112])$ та вкрай розпливчате, оціночне та практично безмежне визначення самого кримінально-караного хуліганства призводить до чималих труднощів та зловживань при кваліфікації відповідних діянь. Навіть фахівці, спираючись на рекомендації вищих судових органів, у коментарях до кримінального закону дають дуже дивні визначення умисного вбивства з хуліганських мотивів: «умисне вбивство, вчинене на грунті явної неповаги до суспільства, нехтування загальнолюдськими правилами співжиття i нормами моралі, а так само умисне вбивство без будь-якої причини чи з використанням малозначного приводу» $[11,268 ; 17,251]$. Який привід визнається значним для вчинення вбивства не зрозуміло. Принаймні мова за логікою повинна йтися про щось менш значне ніж помста, ревнощі, неприязні стосунки, п'яна бійка тощо, оскільки вчинення вбивства через останні передбачає менш суворе покарання (за ч. 1 ст. 115 КК України). А вчинення особою будь-якого діяння без будь-якої причини наводить щонайменш на думку про іï неосудність.

Недостатня термінологічна визначеність кримінального закону та плутані та часом помилкові рекомендації вищих судових органів призводять до помилок у кваліфікації й такого злочину, як умисне вбивство, поєднане із зґвалтуванням або насильницьким задоволенням статевої пристрасті неприродним способом, зокрема до непотрібної додаткової кваліфікації даного діяння ще й за сукупністю
3 п. 9 ч. 2 ст. 115 КК України і відповідними частинами ст. 152 чи ст. 153 КК України. [20]. Це, штучно збільшуючи кількість реєструємих злочинів, призводить до викривлення кримінологічної «картини» як структури вбивств, так й насильницької злочинності в цілому.

3 іншого боку викривленню відповідної кримінологічної «картини» сприяє відображення вбивства двох та більше осіб в відомчій статистичній звітності в якості одного злочину (п. 1 ч. 2 ст. 115 КК України). Оскільки даний склад злочину передбачає відповідальність за вбивство декількох осіб, якщо дії винного охоплювалися єдиним умислом, незалежно від відриву у часі, така кваліфікація цілком не відповідає, наприклад, кримінологічній сутності вбивств маніяка, який вирішив вбити та вбиває стільки людей, скільки кліток на дошці для шахів. В даному контексті цілком слушною $є$ думка, що статистика вбивств повинна охоплювати не лише реєстрацію самих фактів воивств та осіб, що їх скоїли, але й жертв даних злочинів.

В низці випадків законодавець розглядає умисне позбавлення життя іншої людини як злочин проти іншого (відносно Розділу II Особливої частини КК України) родового об'єкту, що вчиняється шляхом застосування насильства (позбавлення життя) задля досягнення певних цілей. 3 метою запобігання викривлення кримінологічної «картини»насильницької злочинності необхідним, на наш погляд, є виключення з Особливої частини ҚК України норм, що є спеціальними по відношенню до ст. 115 КК України (ст.ст. 348, 379, ч. 4 ст. 404 КК України тощо) та відповідне вдосконалення формулювання п. 8 ч. 2 ст. 115 КК України - «вбивство особи чи іiі близького родича у зв'язку з виконанням цією особою службового або громадського обов'язку». Це дозволить концентрувати інформацію про такого роду вбивства в статистичній звітності саме у розділі злочинів проти життя та здоров'я та не «розсіювати» вбивства, знижуючи гостроту проблеми.

Що стосується недоліків та помилок застосування кримінального законодавства окремими правозастосувачами, як фактору латентності вбивств як суміжного стану, то суть його полягає у наступному. Дані недоліки та помилки мають місце внаслідок, поперше, дефіциту кадрів та недосконалості 
професійної підготовки відповідних працівників правоохоронних та судових органів; по-друге, внаслідок недостатнього матеріально-технічного забезпечення відповідної діяльності та недоліків існуючої системи професійного стимулювання та контролю (нагляду).

Розглянемо вказані фактори латентності вбивств на прикладі органів внутрішніх справ, оскільки це найбільш численний правоохоронний орган у державі, саме у компетенції якого знаходяться реєстрація і розслідування вбивств.

Системна криза, що вразила країну з початку 90-х рр. (розбалансованість економіки, падіння життєвого рівня населення, інфляція тощо), та іï насамперед економічні наслідки призвели до стихійної стратифікації суспільства, падіння соціального статусу працівників органів внутрішніх справ, девальвації системи соціального захисту правоохоронців. Наслідком кризи $є$ також практика неповного бюджетного фінансування правоохоронної діяльності $[5,134]$. Не зважаючи на зусилля щодо реформування системи правоохоронних органів та виходу з вказаної ситуації, які можна було спостерігати останнє десятиріччя, остання криза (яку також можна вважати системною з огляду на сполучення вітчизняних соціально-політичних та світових фінансових негараздів) сприяє залишенню актуальності питання та фактичного положення справ практично на тому ж рівні. Крім загальних проблем економічного характеру, необхідно відзначити недиференційованість оплати праці в різних службах і підрозділах без урахування оперативної обстановки, навантаження та результатів роботи кожного.

Кажучи про недоліки кадрового забезпечення, необхідно зазначити, що основна проблема полягає не лише в недоліках діяльності кадрового апарату, але й в цілісному зниженні загальноосвітнього рівня населення, втратою престижу служби в ОВС. Проблеми економічного та матеріально-технічного характеру роблять сьогодні службу в ОВС непривабливою не лише для багатьох громадян, але й самих працівників, що є причиною значного відтоку висококваліфікованого персоналу органів внутрішніх справ, дефіциту кандидатів на службу і як наслідок, кадрової нестабільності в ОВС. Падіння престижу служби стало чинником, який обумовлює наразі хронічну неспроможність підрозділів по роботі з персоналом утримати молодих фахівців на службі. Одночасно скорочується кількість осіб, що навчаються у ВНЗ MBC. При цьому скорочуються й самі $\mathrm{BH}$ МBC (в тому числі ті, що спеціалізуються на підготовці слідчих), негативні наслідки чого на фоні вказаних факторів, а також очікуваного реформування органів прокуратури з орієнтацією на виконання суто наглядових функцій, не заставлять себе довго чекати.

У свою чергу, відсутність конкуренції на вакантні посади, що $є$ результатом реакції громадян на соціальну дезорганізацію системи OBC, змушує вирішувати кадрові проблеми, найчастіше ігноруючи якісні характеристики кандидатів на службу. Керівниками служб і підрозділів ОВС у силу дефіциту кадрів досить часто застосовується практика призначення щойно прибулих працівників на ту чи іншу посаду не відповідно до специфіки отриманої ними спеціалізації, а через некомплект кадрів у тій або іншій службі або підрозділі на поточний момент. Не знаючи специфіки покладених на нього посадових обов'язків, не маючи відповідних знань і навичок, працівник OBC знаходиться часом у безвихідному становищі, результатом чого є професійні помилки або зловживання.

Щодо професійних вмінь та навичок працівників органів внутрішніх справ, то часто, нажаль, рівень останніх не відповідає вимогам. Чимала частка працівників органів внутрішніх справ, які не одержали відповідної вищої освіти, зрозуміло, не мала можливості набути професійних навичок та уміння на стадії навчання. Реальний рівень освіти та професійних знань, за даними дослідниківполіцеїстів, постійно залишає бажати кращого. Особливо це стосується потреби ОВС в юристах вищої кваліфікації [3, 119; 5, 164; 9, 270-273; 8, 258; 19, 63]. На стадії адаптації працівника ОВС в конкретному підрозділі або службі, коли відбувається закріплення та удосконалення професійних вмінь і навичок, також спостерігається низка недоопрацювань. Міністерство внутрішніх справ не раз звертало увагу керівників на те, за молодими працівниками закріплюються наставники без відповідного досвіду, не організовується якісне стажування випускників BН3 MBC і 
курсів початкової підготовки для засвоєння ними необхідних вмінь і навичок. Таким чином, багато працівників органів внутрішніх справ в силу зазначених вище обставин, не набувши необхідних знань та досвіду роботи, об'єктивно не можуть належним чином виконувати свої професійні обов'язки.

Це стосується не лише безпосередньо слідчих, які розслідують вбивства, які не маючи відповідних знань та досвіду, стикаючись 3 проблемою кваліфікації даних злочинів, або допускають помилки, або намагаються відмовити в порушенні кримінальної справи за відповідною статтею чи вигідним чином перекваліфікувати вчинене злочинне діяння (у даному та подібних випадках часто має місце трансформація суміжного стану латентності вбивств у пряме переховування останніх). Це стосується й оперативних працівників, які стикаються з даною проблемою, а матеріали повинні передавати слідчому, який сам не знає, що з ними робити, або ж навпаки не прийме неякісний матеріал. В кінцевому підсумку це стосується й працівника чергової частини, який розуміє й поділяє проблеми останніх.

Незадовільне матеріально-технічне забезпечення OBC, зокрема слідчих підрозділів на сьогодні - проблема більшості регіонів. У деяких райвідділах умови праці вкрай негативно впливають на кінцеві результати праці працівників: комп'ютерами, до того ж переважно застарілими, слідчі забезпечені максимум на $40 \%$ (у цілому по Україні наявність комп'ютерної техніки, необхідної для забезпечення оптимальних умов функціонування робочого місця слідчого, не перевищує 50 \%), 3 витратними матеріалами - як за часів тотального дефіциту, визначені відповідним наказом норм належності організаційної, криміналістичної та спеціальної техніки, засобами зв'язку є поняттям суто абстрактним. Найяскравіше необхідність створення слідчим цивілізованих умов праці ілюструє ситуація у м. Їрпінь, що мала місце не так давно: «на тому поверсі міськвідділу, де розташовані кабінети слідчих, взагалі немає електричного освітлення. Замість комп'ютерів вони повинні користуватися свічками та ліхтариками» $[13,7]$. В свою чергу, недостатня розробленість проблеми законодавчого закріплення та фактичного забезпечення правового і соціального стану викликає непевність окремих працівників правоохоронних органів у доцільності своїх дій, приводить до соціальної і професійної апатії.

Усугубляє ситуацію та сприяє помилкам та недолікам в діяльності працівників правоохоронних органів, що в кінцевому підсумку сприяють латентності вбивств, також перевантаженість та ненормованість робочого часу пращівників $O B C$.

Наявність у провадженні одного слідчого підчас одночасно декілька десятків кримінальних справ або оперативних матеріалів у оперуповноваженого чи дільничного інспектора призводять до деструктивно напруженої праці. Відомчі дослідження фіксують середню тривалість робочого дня - 11-15 годин для служб карного розшуку, слідства, дільничних інспекторів міліції з інтервалом між вихідними до 15 днів [12, 82]. Безумовно, такий графік роботи, а точніше сказати, графік «використання працівника ОВС» приводить до його виснаження, що негативно позначається на якості роботи. Слід враховувати, що останні роки спостерігається тенденція до збільшення кількості злочинів підслідних слідчим органів внутрішніх справ. Загалом на сьогодні слідчими органів внутрішніх справ розслідується не менш ніж $90 \%$ всіх кримінальних справ, що перебувають у провадженні правоохоронних органів. Що стосується безпосередньо вбивств, то слід також враховувати, що на момент передачі вбивств 3 підслідності прокуратури органам внутрішніх справ, розслідуванням злочинів проти життя та здоров'я у прокуратурі займалося близько 1,5 тисяч слідчих, що практично втричі перевищувало штатну чисельність відповідних відділів ОВС. До того ж слід додати, що слідчі ОВС, окрім розслідування злочинів, також залучаються до оглядів місць виявлення трупів некримінального характеру (без ознак насильницької смерті та інших ознак злочину) з метою проведення перевірки та у відповідних випадках виносять постанову про відмову в порушенні кримінальної справи. Безумовно така діяльність збільшує навантаження слідчого та забирає час і відволікає від розслідування кримінальних справ. Отже, не дивно, що помилки у кваліфікації та недоліки розслідування (як і приховування злочинів від обліку та фальсифікація доказів, але про це окремо) 
почасти $€$ часом прямим наслідком безвихідного становища працівників органів внутрішніх справ, загнаних у глухий кут дефіцитом часу та надмірним навантаженням.

Також до факторів детермінації даного виду латентності вбивств слід віднести недоліки організаційно-управлінської діяльності правоохоронних органів щодо виявлення, реєстрації та розкриття цих злочинів. Так, часто: 1) слідчо-оперативні групи на місця подій направляються не своєчасно (навіть не в день скоєння злочину); 2) при формуванні слідчо-оперативної групи і направленні iï на місце подіï не враховується ступінь кваліфікації працівників та їх спеціалізація (особливо слідчих), які до неї включаються; 3) огляд місця події нерідко проводиться без спеціалістів-криміналістів та судово-медичного експерта або до огляду місця події направляються фахівці, що не мають необхідних допусків для проведення відповідної роботи; 4) плани погоджених слідчих дій та оперативно-розшукових заходів складаються формально, у подальшому не корегуються; 5) більшість можливих версій щодо розслідування кримінальних справ по вбивствах не відпрацьовуються, а зводяться до перевірки близьких потерпілому осіб чи раніше судимих та осіб, які перебувають на профілактичних обліках тощо; 6) необхідні слідчі дії проводяться не вчасно або взагалі не проводяться; 7) через не своєчасне або некваліфіковане проведення судово-медичних та інших експертиз розслідування злочинів цієї категорії затягується тощо.

Нині визнається, що діяльність МВС повинна бути прозорою (за винятком певної частини слідчих та оперативно-розшукових дій) для забезпечення іiі гласності, можливості контролювання законності та ефективності $з$ боку державних органів та населення. Проте, слід констатувати, що наразі спостерігаються вади в організаціі не лише громадського контролю, але й відомчого, у тому числі з боку ряду керівників. Серед причин та умов порушень законності працівниками органів внутрішніх справ фахівці визначають: безвідповідальність і безконтрольність з боку керівництва УМВС в областях за втіленням у життя рішень колегії MBC на місцях; відсутність належної роботи кураторів УМВС в областях має наслідком необізнаність щодо істинного стану справ на місцях, і як наслідок - неможливість впливу на нього; недоведення керівниками вимог колегій до відома особового складу міськрайлінорганів [5, 190-191]. Діяльність ж населення в особі різних неурядових і громадських організацій щодо контролю за діяльністю ОВС в останні роки поступово активізується. Однак нерідко у підрозділах та службах ОВС робота громадських формувань залишається як і раніше формальною, «на папері» $[12,67]$.

Висновки. Отже, латентність вбивств як суміжний (між природною та штучною латентністю) стан обумовлюється існуванням факторів, через які особи, які виявили факт ї вчинення, через неясність ситуації чи неправильну правову оцінку не повідомляють про це в правоохоронні органи (або належним чином чи взагалі не реєструють ї). Враховуючи специфіку вбивства, мова повинна йтися про професійну діяльність працівників органів охорони здоров'я та правоохоронних органів. Також обумовлюють латентність вбивств як суміжного стану труднощі кримінально-правової оцінки, пов'язані з недосконалістю кримінального законодавства та недоліками та/ або помилками його застосування окремими правозастосувачами. Сутність останніх полягає у тому, що дані недоліки та помилки мають місце внаслідок, по-перше, дефіциту кадрів та недосконалості професійної підготовки відповідних працівників правоохоронних та судових органів; по-друге, внаслідок недостатнього матеріально-технічного забезпечення відповідної діяльності та недоліків існуючої системи професійного стимулювання та контролю (нагляду). Чималу роль в латентизації вбивств грають недоліки організаційно-управлінської діяльності правоохоронних органів щодо виявлення, реєстрації та розкриття цих злочинів. 


\section{Jimepamypa:}

1. Антонян Ю. М. Криминология : избранные лекции / Ю. М. Антонян- М. : Логос, 2004. - 448 с.

2. Абельцев С. Н. Преступления против личности и проблема криминального насилия / С. Н. Абельцев // Закон и право. - 1998. - № 8. - С. 12-15.

3. Бандурка О. М. Теорія та методи роботи 3 персоналом в органах внутрішніх справ : підручник / О. М. Бандурка, В. О. Соболєв. - Х. : Вид-во Ун-ту внутр. справ, 2000. - 480 с.

4. Зелінський А. Ф. Кримінологія : навч. посіб. / А. Ф. Зелінський. - Х. : Рубікон, 2000. - 260 с.

5. І гнатов О. М. Насильницькі злочини, що вчиняються працівниками органів внутрішніх справ України: кримінологічна характеристика, детермінація та попередження : монографія / О. М. Їнатов. - Х. : Формат Плюс, 2008. - 296 с.

6. Іігнатов О. М. Насильство як спосіб вчинення злочину: поняття та сутність / О. М. Іेгнатов // Форум права. - 2010. - № 3. - С. 144-151 [Електронний peсурс]. - Режим доступу : http://www.nbuv.gov.ua/ejournals/FP/2010-3/10iomptc.pdf

7. І Іेнатов О. М. Протидія кримінальному насильству потребує вдосконалення кримінального законодавства / О. М. Їгнатов // Актуальні проблеми кримінального права та кримінології, кримінально-виконавчого права : Матеріали III Міжнародної науково-практичної конференції «Актуальні проблеми кримінального права, процесу та криміналістики», присвяченої 10-річчю Міжнародного гуманітарного університету (м. Одеса, 28 жовтня 2011 року). - Одеса : Фенікс 2011. - С. 343-345.

8. Кравченко Ю. Ф. Свобода як принцип демократичної правової держави: дис. ... д-ра. юрид. наук: 12.00 .01 / Ю. Ф. Кравченко - Х., 2003. - 390 с.

9. Мартыненко О. А. Детерминация и предупреждение преступности среди персонала органов внутренних дел Украины : монография / О. А. Мартыненко. - Х. : Изд-во ХНУВС, 2005. - 468 с.

10. Насимов Г. А. Причины и меры предупреждения убийств: дис. .... кандидата юрид. наук : 12.00 .08 / Г. А. Насимов. - М., 2004. - Сc. 203-204.

11. Науково-практичний коментар Кримінального кодексу України. - 4-те вид., переробл. та доповн. / За ред. М. І̇. Мельника, М. І̇. Хавронюка. - К. : Юридична думка, 2007. - 1184 с.

12. Новиков М. М. Правові аспекти забезпечення психоемоційної стабільності працівників ОВС України / М. М. Новиков, Т. Г. Зайцева // Нормативно-правове забезпечення проходження служби в органах внутрішніх справ. - Х. : Вид-во Нац. ун-ту внутр. справ, 2004. $-194 \mathrm{c}$.

13. Обертинський О. Чи працюватиме комп'ютер без електрики? Або що гальмує якість слідства / О. Обертинський // І̇менем Закону. - № 42 (5636) 17.10.2008 - 23.10.2008. - C. 7 .

14. Оболенцев В. Ф. Актуальні проблеми латентної злочинності: дис. ... канд. юрид. наук : 12.00 .08 / В. Ф. Оболенцев - Х., 2001. - 185 с.

15. Синявська О. Ю. Засоби забезпечення службової дисципліни в органах внутрішніх справ України (організаційно-правові питання): дис.... канд. юрид. наук: 12.00.07 / О. Ю Синявська. - Х., 2001.-200 с.

16. Сташис В. В. Вступне слово / В. В. Сташис // Кримінально-правова охорона життя та здоров'я особи : Матер. наук.-практ. конф. [Харків] 22-23 квітня 2004 р. / Редкол.: Сташис В. В. (голов. ред.) та ін. - К.-Х. : Юрінком Їнтер, 2004. - С. 5-8.

17. Уголовный кодекс Украины : научно-практический комментарий / Отв. ред. Е. Л. Стрельцов. - Издание седьмое, переработанное и дополненное - Х. : Одиссей, 2010. - 904 с.
18. Хавронюк М. І̇. Кримінальне законодавство України та інших держав континентальної Європи: порівняльний аналіз, проблеми гармонізації : монографія / М. І̇. Хавронюк. - К. : Юрисконсульт, 2006. - 1048 с.

19. Шалгунова С. А. Кримінально-правові та кримінологічні заходи попередження хабарництва серед співробітників органів внутрішніх справ: дис. ... канд. юрид. наук : 12.00.08 / С. А. Шалгунова. - К., 1999. 203 c.

20. Шигонін О. Б. Відмежування складів злочинів, передбачених п. 9 і п. 10 ч. 2 ст. 115 КК України / О. Б. Шигонін // Вісник прокуратури. - 2010. - № 6 (108). - C. 61-65.

\section{Игнатов А. Н. Латентность убийств как смежное состояние \\ Аннотация. Статья посвящена исследова-} нию факторов латентности насильственной преступности на примере такого преступления как убийство. Установлены факторы латентности убийств как смежного состояния и дана их общая характеристика.

Ключевые слова: латентность, убийство, фактор, смежное состояние.

Ignatov A.N. Latentness of murders as the contiguous state

Summary. The article is devoted research of factors of latentness of violent criminality on the example of such crime as murder. The factors of latentness of murders as the contiguous state are set and their general description is given.

Keywords: latentness, murder, factor, contiguous state. 